\title{
Innovation-Oriented Way in Regional Economic Development
}

\author{
Ovchinnikova T.I.* \\ Voronezh State University of Engineering Technologies \\ Voronezh, Russia \\ e-mail: mih.goz@gmail.com
}

\author{
Davydenko I.A. \\ Voronezh State University of Engineering Technologies \\ Voronezh, Russia \\ e-mail: zorina9@yandex.ru \\ Platonova I.V. \\ Voronezh State University of Engineering Technologies \\ Voronezh, Russia \\ e-mail: aniri_78@mail.ru
}

\author{
Elagina T.V. \\ Voronezh State University of Engineering Technologies \\ Voronezh, Russia \\ e-mail: elagina1997@inbox.ru
}

\begin{abstract}
The article deals with the features of innovationoriented development of regional economies. It leads to the appearance of preferences in the economy and society formation. Regional development creates the basis for growth of economic potential in the sphere of entrepreneurship development, optimization of infrastructure and introduction of innovations. At the same time, the increase of the state influence on the economy contributes to the fall of investments in the regions, reduces the development of the banking system, etc. In order to overcome the protracted economic crisis in the country and the regions, the authors propose to intensify the development and introduction of high technologies by removing administrative barriers in the sphere of entrepreneurial activity, expanding the technoparks, creating the necessary conditions for the optimization of the centers for issuing patents and permits that meet international standards. Factors hampering the development of regions, as well as tasks in the field of competitive development of regions are considered. It is proposed to synchronize investment and innovation plans for the development of regions with the long-term development strategy of the Russian Federation, taking into account the innovation infrastructure.
\end{abstract}

Keywords - regional development, innovation-oriented, knowledge economy, regional competitiveness, industrial cluster.

\section{INTRODUCTION}

Competitive formation of the Russian Federation's economy is possible through optimal growth of each region and contributes to the improvement of living standards and quality of life. Formation and development of economic potential of the region at the expense of own resources create the basis for growth of economy of the Russian Federation. Regional enterprises (both state and private) are important for prospective development of the state, as they are:
- To perform state tasks to ensure the country's security (defense, food, information, intellectual, etc.);

- To care of the development of the social sphere by attracting workers to work and paying taxes properly.

Regional development is also facilitated by the growth of entrepreneurship, innovation and infrastructure optimization, which leads to the creation of conditions for increased socialization of the population.

In 2009, a presidential decree established the Commission for Modernization and Technological Development of the Russian Economy, the main task of which is to transfer the Russian economy to an innovative path of development in five major areas:

- introduction of new energy-efficient technologies, including environmentally friendly renewable energy sources;

- information technologies, including supercomputers and software, and their implementation in all sectors of the national economy;

- telecommunications technologies, including mobile broadband Internet access technologies;

- nuclear technologies, including those used in energy, medicine, space sphere, etc.

- medical technologies, including the creation of new equipment and medicines.

The main requirement for these five areas is their innovative orientation and global competitiveness. Technologies of construction of innovative economy of the region depend on the decision of many problems, including optimization of organizational and enterprise structures, 
development of an infrastructure, reception of investments, development of educational and qualifying level of its inhabitants.

\section{RESULTS}

The problems of regional economies should be addressed comprehensively, as they are a task not only for organizations, regions, but for the state as a whole. At the same time, the influence of federal authorities on the development of the region is twofold: on the one hand, it is subsidies and investments in the development of enterprises in the region. On the other hand, it is centralization and strict tax pressure aimed not at the strategic development of breakthrough technologies, but at «patching up permanent holes». This prevents the regions from becoming competitive. By competitiveness of regions authors understand market preferences of territories, manufactures, techniques, technologies, and also the markets creating social and economic effect taking into account use of competent personnel, informatization and digitalization of manufactures and service sphere.

Another factor that undermines the competitiveness of the region is economic crime. Thus, the struggle for land plots, real estate, and property is not always conducted in the legal field; raiding is significant (Fig. 1).

The current state of the regional economy is affected by the protracted economic crisis that has lasted since 2008. The formed powerful scientific-technical, industrial, agricultural, intellectual potential was lost due to the wrong strategy of transformations in the 90s: removal of the state from regulation of economic processes, inefficient total privatization, «staff leakage», including scientific. This led to the lag of the Russian Federation and its regions in social and economic development. The expansion of the state's place in the economy, reduction of investments in regions, declining development of the banking system and other indicators are shown in Table 1.

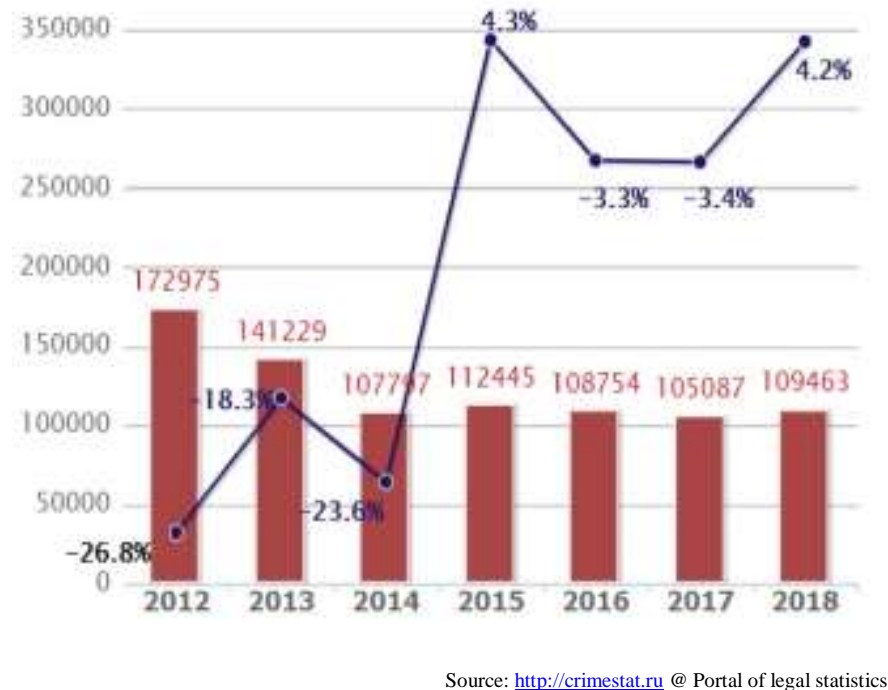

Fig. 1. Dynamics of revealed economic crimes in the Russian Federation

TABLE I.

DYNAMICS OF ECONOMIC DEVELOPMENT INDICATORS IN THE RUSSIAN FEDERATION

\begin{tabular}{|c|c|c|c|c|}
\hline Directions of the economic model & Indicators & 2014 & 2015 & 2016 \\
\hline Public expenses [2] & $\begin{array}{l}\text { Public expenses, including for pension provision (\% of } \\
\text { GDP) }\end{array}$ & 8.7 & 9.9 & 9.8 \\
\hline Government spending [3] & State budget expenditures, $\%$ of GDP & 17 & 17 & 18 \\
\hline Investment climate and business conditions [4] & The share of taxes in GDP, $\%$ & 13.9 & 11.2 & 11.0 \\
\hline Agriculture development [4] & Share of employed in agriculture, $\%$ & 6.7 & 6.7 & 6.7 \\
\hline Banking and credit system [5] & $\begin{array}{l}\text { The volume of loans issued by the banking sector } \\
\text { within the country, } \% \text { of GDP }\end{array}$ & 0.44 & 0.42 & 0.40 \\
\hline Financial System [4] & $\begin{array}{l}\text { Net financial assistance to foreign countries (received } \\
\text { from foreign countries), \% of GDP }\end{array}$ & 0.008 & 0.007 & 0.006 \\
\hline Foreign economic activity & Share of Internet users for commercial purposes, $\%$ & 68.8 & 69.4 & 70.5 \\
\hline Labor market & Unemployment, \% of labor & 5.5 & 5.2 & 5.6 \\
\hline $\begin{array}{l}\text { National income distribution system and wealth } \\
\text { management }\end{array}$ & GDP per capita (thousand rubles) & 541.35 & 569.19 & 585.27 \\
\hline Social structure and state of the social sphere [6] & Health expenditures, USD per capita & 827 & 815 & 850 \\
\hline The level of militarization of the economy [7] & Military spending, $\%$ of GDP & 3.4 & 3.7 & 4.7 \\
\hline Demographic features & Average age, number of years & 70 & 70 & 70 \\
\hline
\end{tabular}

TABLE II. COMPARATIVE SOCIO-ECONOMIC INDICATORS CHARACTERIZING THE AGGREGATE ELEMENTS OF PRODUCTIVE FORCES IN THE CENTRAL FEDERAL DISTRICT REGIONS

\begin{tabular}{|c|c|c|c|c|c|c|c|c|}
\hline $\begin{array}{l}\text { Central Federal District } \\
\text { / Indicators }\end{array}$ & $\begin{array}{c}\text { GRP } \\
\text { billion rub. }\end{array}$ & $\begin{array}{c}\text { GRP per } \\
\text { capita, mln. } \\
\text { rub. }\end{array}$ & $\begin{array}{c}\text { Productivity, } \\
\%\end{array}$ & $\begin{array}{c}\text { Natural } \\
\text { population } \\
\text { growth, people }\end{array}$ & $\begin{array}{l}\text { Fixed assets } \\
\text { renewal, } \%\end{array}$ & $\begin{array}{l}\text { Fixed capital } \\
\text { investments, } \%\end{array}$ & $\begin{array}{l}\text { The presence } \\
\text { of clusters }\end{array}$ & $\begin{array}{c}\text { Grants, } \\
\text { billion rubles }\end{array}$ \\
\hline Tambov Region & 236 & 219948 & 4.5 & -6667 & 6.2 & 37.7 & 2 & 71 \\
\hline Kursk region & 168 & 144519 & 4.3 & -5173 & 6.4 & 52.1 & 5 & 19 \\
\hline Oryol Region & 179 & 234157 & 4.2 & -3900 & 8.5 & 20.8 & 4 & 6.6 \\
\hline Bryansk region & 686 & 443000 & 4.7 & -3717 & 7.4 & 54.8 & 5 & 56 \\
\hline Lipetsk region & 315 & 341455 & 4.1 & -4297 & 6.6 & 30.0 & 11 & 145 \\
\hline Voronezh region & 709 & 352926 & 4.4 & +1317 & 9.5 & 36.6 & 6 & 390 \\
\hline
\end{tabular}


The dynamics of the socio-economic development of the Russian Federation undoubtedly also have an impact on the development of regional economies. Comparative socioeconomic characteristics of the Central Federal District (CFD) regions development are shown in Table 2.

In the development (both in theoretical and practical terms) the country as a whole and its regions did not take into account rational economic positions of Keynesian theories, rational expectations and, the main thing, innovative economic theory directing applied development of economy.

For example, it is known that the postindustrial society is characterized by development of innovations. The «Concept2020» of development of the Russian Federation sets the task of systematic «transition of the Russian economy from export raw materials to innovative socially oriented type of development» [8]. Investments in innovations in dynamics are shown in Table 3.

TABLE III. INVESTMENTS IN FIXED ASSETS BY SUBJECTS OF THE RUSSIAN FEDERATION, MLN. RBL.

\begin{tabular}{|l|c|c|c|c|c|c|c|c|c|}
\hline \multicolumn{1}{|c|}{ Districts } & 2010 & 2011 & 2012 & 2013 & 2014 & 2015 & 2016 & 2017 & 2018 \\
\hline Russian Federation & $\mathbf{9 1 5 2 0 9 6}$ & $\mathbf{1 1 0 3 5 6 5 2}$ & $\mathbf{1 2 5 8 6 0 9 0}$ & $\mathbf{1 3 4 5 0 2 3 8}$ & $\mathbf{1 3 9 0 2 6 4 5}$ & $\mathbf{1 3 8 9 7 1 8 8}$ & $\mathbf{1 4 7 4 8 8 4 7}$ & $\mathbf{1 6 0 2 7 3 0 2}$ & $\mathbf{1 7 7 8 2 0 1 2}$ \\
\hline $\begin{array}{l}\text { Central Federal } \\
\text { District }\end{array}$ & $\mathbf{2 0 9 9 8 2 4}$ & $\mathbf{2 4 5 8 3 1 2}$ & $\mathbf{2 9 6 1 5 8 4}$ & $\mathbf{3 3 3 1 6 2 9}$ & $\mathbf{3 5 7 0 4 3 2}$ & $\mathbf{3 5 7 8 1 8 6}$ & $\mathbf{3 7 9 5 4 2 2}$ & $\mathbf{4 2 4 1 5 1 9}$ & $\mathbf{4 9 9 8 0 1 8}$ \\
\hline Tambov Region & 53980 & 68302 & 82921 & 98227 & 110597 & 117641 & 105033 & 111073 & 106230 \\
\hline Kursk region & 46093 & 58521 & 66639 & 71546 & 73695 & 73745 & 93659 & 100895 & 120735 \\
\hline Oryol Region & 21451 & 34072 & 40429 & 43741 & 47580 & 47981 & 43596 & 43670 & 48058 \\
\hline Bryansk region & 41989 & 48014 & 46551 & 60864 & 66066 & 62255 & 68195 & 55121 & 58918 \\
\hline Lipetsk region & 101600 & 112531 & 93327 & 101093 & 105588 & 116134 & 127891 & 142407 & 128533 \\
\hline Voronezh region & 125826 & 155245 & 182334 & 216983 & 240272 & 264660 & 270992 & 283652 & 276785 \\
\hline
\end{tabular}

The analysis of statistical data shows that in order to overcome crisis phenomena in the regional economy, the priority measure should be systematic work on formation of breakthrough priorities of economic development, i.e. the regions should switch to investment and innovation competitive model of economy. For this purpose it is necessary:

- to develop and introduce high technologies into production;

- to expand the geography of technoparks;

- to continue the work on removal of administrative barriers in the sphere of entrepreneurial activity;

- to create conditions for optimization of the activity of the centers for issuing patents and permits on the principle of not only organizational unity, but also taking into account compliance with international standards.

\section{DISCUSSION}

At the present stage, not only the development of innovations is important, but also the receptivity of regional economies to them. In particular, the educational system formed in recent years in the Russian Federation allows regions to move to the knowledge economy. Thus, in the program of social and economic development of the Voronezh

region [9] long-term plans to ensure the competitiveness of regional economies not only in the development of the Russian Federation, but also taking into account European integration have been developed (Table 4).

At present, the long-term and medium-term development plans of regions for the purpose of increasing their competitiveness contain the provisions shown in Fig. 2.
TABLE IV. NUMBER OF STUDENTS IN HIGHER EDUCATION INSTITUTIONS OF THE CENTRAL FEDERAL DISTRICT, THOUSAND PERSONS

\begin{tabular}{|l|c|c|c|c|c|}
\hline $\begin{array}{c}\text { The number of } \\
\text { students in } \\
\text { universities }\end{array}$ & 2014 & 2015 & 2016 & 2017 & 2018 \\
\hline Russian Federation & $\mathbf{5 2 0 9 . 0}$ & $\mathbf{4 7 6 6 . 5}$ & $\mathbf{4 3 9 9 . 5}$ & $\mathbf{4 2 4 5 . 9}$ & $\mathbf{4 1 6 1 . 7}$ \\
\hline $\begin{array}{l}\text { Central Federal } \\
\text { District }\end{array}$ & $\mathbf{1 5 7 7 . 9}$ & $\mathbf{1 4 5 5 . 3}$ & $\mathbf{1 3 5 9 . 6}$ & $\mathbf{1 3 0 3 . 9}$ & $\mathbf{1 2 8 6 . 6}$ \\
\hline Tambov Region & 33.1 & 29.2 & 29.7 & 28.6 & 27.8 \\
\hline Kursk region & 55.7 & 54.6 & 44.5 & 41.1 & 38.0 \\
\hline Oryol Region & 33.5 & 31.9 & 30.7 & 30.9 & 30.3 \\
\hline Bryansk region & 39.5 & 34.5 & 30.7 & 27.0 & 25.3 \\
\hline Lipetsk region & 28.5 & 24.9 & 22.2 & 21.7 & 21.2 \\
\hline Voronezh region & 99.0 & 91.8 & 88.9 & 87.0 & 86.0 \\
\hline
\end{tabular}

\begin{tabular}{|l|l|}
\hline \multicolumn{3}{|c|}{$\begin{array}{l}\text { Factors for accelerating the growth rate } \\
\text { of the Russian national economy }\end{array}$} \\
\begin{tabular}{|l|l|}
\hline $\begin{array}{l}\text { 1) the presence of the visual } \\
\text { potential of a highly skilled } \\
\text { workforce; } \\
\text { 2) the possibility of using } \\
\text { advanced national and foreign } \\
\text { technologies; } \\
\text { 3) the development in Russia of } \\
\text { transnational transport routes } \\
\text { connecting Europe with Asia; } \\
\text { 4) large financial resources } \\
\text { accumulated in the private and } \\
\text { public sectors. }\end{array}$ \\
\hline
\end{tabular}
\end{tabular}

Fig. 2. Factors accelerating the growth rate of the Russian economy.

Scientists and practitioners [10-12], in the long term assume the development of regions through the functioning of knowledge-intensive industries. However, their development is hindered by: the lack of a clear long-term perspective 
(government plans that are constantly changing (V.V. Putin's May edicts, work on import substitution, 12 projects), a strategy aimed at resource extraction and sale (30\% of GDP), capital export, low-skilled labor market, etc.) (Fig. 3).

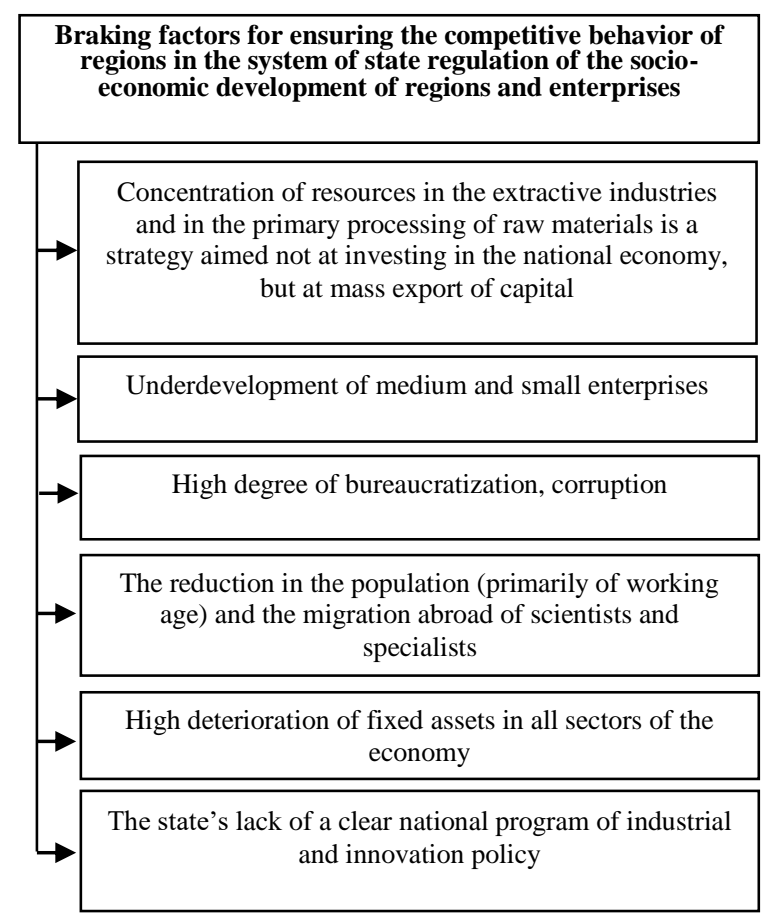

Fig. 3. Factors hindering regional competitiveness (according to the authors [13]).

The provisions of the Voronezh Region Competitiveness Development Strategy are in line with the RF plans. Taking into account the opinion of scientists [14-16], the analysis of socio-economic development of regions functioning on the basis of laws and regulations, the tasks in the field of innovation-oriented development of the Voronezh region have been defined (Fig. 4).

Based on the development of innovation potential in competitive industries, which are the quintessence of scientific and technical innovations, high-tech industries (aircraft manufacturing, rocket and space industry, electronic industry, nuclear power engineering and others) remain promising for the region.

The long-term strategy of investment and innovation development in Voronezh Region also takes into account the development of innovation infrastructure (innovation business incubators, innovation centres, technoparks, technopolises, etc.) and the provision of substantial preferences for scientific teams and enterprises that focus their activities on the implementation of government-defined priorities.

Ensuring the implementation of a competitive state innovation policy is impossible without the protection of intellectual property rights, namely, the creation of information bases for the protection of documents, specially created libraries that guarantee the ability of scientists and practitioners to carry out patent and other scientific and technical activities, taking into account financial, economic, production and social opportunities.

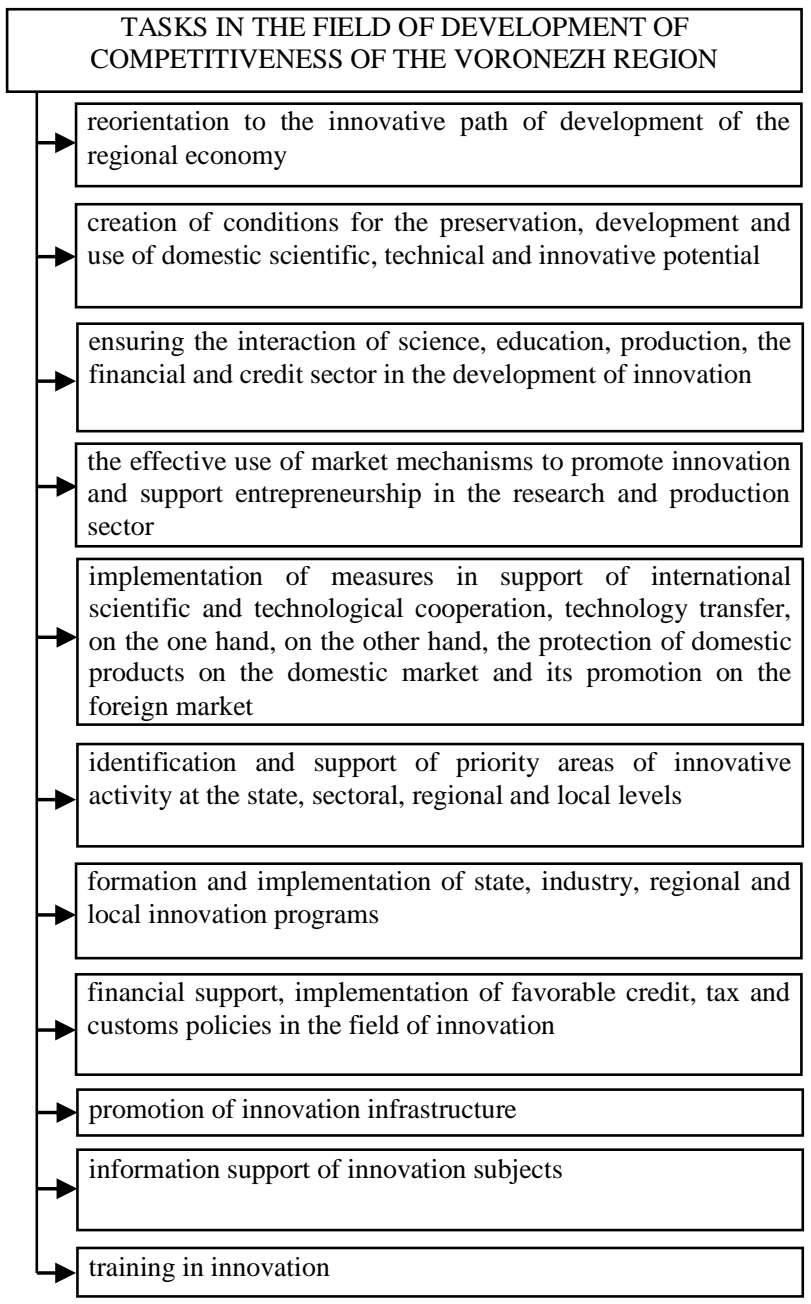

Fig. 4. Challenges to competitive development of the Voronezh Region.

In recent years, the similarity of errors in the innovative development of the regions of the Central Federal District at the planned level is the lack of a system for conjugation of planning at the regional and state levels, incoherence of strategic state and tactical regional plans, constant change of vectors of development.

A serious reason for lagging behind the development of regions are: low professionalism, excessive regulation of laws, rules and procedures that hinder initiative in economic behavior, lack of practical experience of economic activity of the majority of heads of regions at different levels (both those who are elected and those who are appointed).

The potential of the regions is limited due to the traditional approach, although it is the main resource for their development. For example, strategic plans of activities of local executive authorities, as well as those of local self-government bodies, may become one of the main priorities of the regional economy. However, the strategy of effective use of resource 
potential of regions in order to increase their competitiveness insignificantly relies on clustering and network development of economic structures of the region (clusters are voluntary association of economic structures for the purpose of effective development, network structures are the same clusters, but based on development of innovations). Structural and sectoral changes in the economic complex of the regions based on the introduction of investment and innovation model, taking into account the peculiarities of each of them, are slow. Thus, in Voronezh region in 2017 there were only 11 clusters, in Lipetsk region -9 , Belgorod region -11 .

\section{CONCLUSION}

The transition from a sectoral structure to clustering in the global economy is a common trend. Thus, in European countries the practice of implementing cluster initiatives is reflected in regional economic policy. The formation of industrial clusters: construction and building materials, light industry, food production, etc. is gradually growing and is included in regional clusterization programs. "The countries of the European Union are focused on the development of clusters; they ensure the creation of the most competitive and dynamic economic knowledge economy in Europe, capable even ahead of the United States and Japan on indicators of sustainable economic development. The importance of industrial clusters development is testified by the fact that at the Forum of European Chambers in July 2006 the Manifesto of European Chambers on cluster development in Europe was approved and adopted".

The process of accelerating the formation of new innovative production systems in the regions of the Russian Federation on the basis of the cluster model was greatly facilitated by the initiatives of the Government of the Russian Federation when nominating the strategy of 12 projects. In a competitive economy, the reason for lagging behind innovation development is the lack of attention of both scientists and practitioners in «defining a market niche of competitive products», when its solvent demand is studied, and researchers and managers of innovative projects identify the advantages, geography and scale of markets for products created in existing and potential industrial clusters by studying cluster structures

Innovation-oriented form of development of economic enterprises is manifested not only in the transition from sectoral to cluster economy, but also in the study of the impact and implementation of adjustments in economic development plans of regions and their enterprises, consistent with the strategy of state innovation development. The best model for the functioning of regions in terms of competitive innovation development (cost reduction and introduction of innovations by enterprises) has proved to be the most viable model for the plans of enterprises that are part of cluster structures.

\section{References}

[1] The portal of legal statistics. Retrieved from http://crimestat.ru/regions_chart_total.

[2] Annual reports of the Russian Pension Fund for 2014-2016 years Retrieved from: www.pfrf.ru.

[3] Government spending (\% of GDP) (\%) in Russia in 2016 year - World Bank. Retrieved from: http://data.trendeconomy.ru/dataviewer/ $\mathrm{wb} / w b d$ /wdi?ref_area=RUS\&series=NE_CON_GOVT_ZS

[4] Russian statistical yearbook - 2017, Federal state statistics service. Retrieved from: http://www.gks.ru/bgd/regl/b17_13/Main.htm.

[5] Official website of the Central Bank of the Russian Federation Retrieved from: http://cbr.ru/statistics/print.aspx?file=bank_system/4-31_16.htm\&pid=pdko_sub\&sid=dopk.

[6] G.E. Ulumbekova, Healthcare In Russia. The results of the 2012-2016 Urgent measures in 2017-2018. Development priorities up to 2025 , 2017. Retrieved from: http://www.rosmedlib.ru/book/ ISBN9785970443002.html.

[7] I. Plekhanov, "With a calculator at the ready: the West calculates Russia's defense spending", Russ. News Agency Novosti, 2016 Retrieved from: https://ria.ru/20161128/1482326594.html

[8] Scenario conditions of the forecast of the Ministry of economic development for 2017-2020. Retrieved from: https://www.economy. gov.ru.

[9] Program of social and economic development of the Voronezh region. Retrieved from: https://www.govvrn.ru/programma-social-noekonomiceskogo-razvitia-voronezskoj-oblasti.

[10] A.O. Baranov, V.M. Gilmundinov, V.N. Pavlov, "Russian Economy in the coming years", All-Russ. Econ. magazine "ECO”, vol. 12, pp. 113-114, 2012.

[11] E.E. Krasilnikova, "Reasons for slowing economic growth and ways to accelerate it in Russia", Sci. almanac, vol. 8, no. 10, pp. 238-241, 2015.

[12] G. Idrisov, S. Sinelnikov-Murylev, "Budget policy and economic growth”, Econ. issues, vol. 8, pp. 35-59, 2013.

[13] Strategic global forecast 2030, ed. by A.A. Dynkin. Moscow: Magister, 2011.

[14] E.Y. Sheinin, "Institutional environment in the Russian economy: state and problems", World of change, vol. 3, pp. 80-94, 2012.

[15] E.V. Gorkovenko, I.V. Platonova, K.V. Chekudaev, "Analysis of economic security of the Central Black Earth region", Econ. and entrepreneurship, vol. 8-3, no. 85, pp. 253-258, 2017.

[16] T.I. Ovchinnikova, I.A. Davydenko, K.V. Chekudaev, "Increasing employee income: an innovative approach based on a combination of factors of production and consumption", Proc. of VSUET, vol. 81, no. 3 , pp. 261-266, 2019.

[17] The European cluster memorandum. Promoting European Innovation through Clusters: An Agenda for Policy Action. Retrieved from: http://www.clusterobservatory.eu. 